\title{
COMMENTS
}

\section{THE FAIRNESS DOCTRINE TODAY: A CONSTITUTIONAL CURIOSITY AND AN IMPOSSIBLE DREAM}

\author{
THOMAS G. KRATTENMAKER* \\ AND L. A. POWE, JR.**

\section{The FAIRNESS Doctrine}

Immediately followimg the Supreme Court's opinion in Red Lion Broadcasting Co. v. FCC, ${ }^{1}$ which sustained the constitutionality of the Federal Comniunications Commission's (FCC) Fairness Doctrine, ${ }^{2}$ a flurry of articles appeared describing how to apply the doctrine vigorously to new and different situations. ${ }^{3}$ Subsequently, especially after the Court's decision in CBS v. Democratic National Committee 4 curtailed access possibilities, and Miami Herald Publishing Co. v. Tornillo ${ }^{5}$ refused to sustain right to reply laws for candidates attacked by the print media, most discussions of the Fairness Doctrine have addressed its constitutionality. ${ }^{6}$ While initially interesting, this debate has grown as predictably repetitious and unilluminating as a tenth rerun of "Kojak." Furthermore, the debaters appear to have lost track of what the Fairness Doctrine is and how it works.

Our purpose is quite siniple. We seek to rectify these oversights and, in the process, denionstrate that the Fairness Doctrine is incoherent and unworkable. We will also denionstrate that the doctrine as it oper-

* Professor of Law, Georgetown University Law Center.

** Windfohr Professor of Law, The University of Texas. Several people have reviewed earlier drafts of this article and provided especially helpful criticisin. Our thanks to Susan Bloch, Roy Schotland, Michael Seidınan, and Girardeau Spann of Georgetown and David Anderson, Douglas Laycock, Richard Markovits, and Mark Yudof of Texas.

1. 395 U.S. 367 (1969).

2. 47 C.F.R. $\$ 73.1910$ (1983).

3. In one of the longest pure citation footnotes the reader is hikely to encounter, David Lange cites them all. See Lange, The Role of the Access Doctrine in the Regulation of the Mass Media: $A$ Critical Review and Assessment, 52 N.C.L. REv. 1, 2 n.5 (1973).

4. 412 U.S. 94 (1973).

5. 418 U.S. 241 (1974).

6. Much of this literature is discussed in Van Alstyne, The Möbius Strip of the First Amendment: Perspectives on Red Lion, 29 S.C.L. REv. 539 (1978). 
ates is wholly incongruous with the Fairness Doctrine its remaining supporters describe. Our conclusion is that the Fairness Doctrine does not-and cannot-work. Accordingly it should be repealed either by legislative or administrative action.

The Fairness Doctrine, promulgated by the FCC several decades ago, ${ }^{7}$ purports to require that radio and television broadcast station licensees give adequate coverage to significant public issues and ensure that such coverage is fair in that it accurately presents conflicting views on those issues. ${ }^{8}$ Probably no law more clearly reflects the unique balance of regulatory techniques by which the United States governs its broadcast industry. Broadcasters are to be hicensed to use, but not own, the radio spectrum. ${ }^{9}$ Once licensed, they are to be controlled principally by the forces of coinpetition ratlier tlian by governinent control or production of their programs or schedules. ${ }^{10}$ Yet, while pursuing profits, these licensees are also to act as public trustees of the airwaves. ${ }^{11}$

The Fairness Doctrine tluus stands as a symbol of what Americans hope for froin the radio and television industry: neutral, detached presentation of significant public issues. Sucli reportage should inform without indoctrinatimg, producing an enliglitened citizenry but avoiding

7. The general Fairness Doctrine is now incorporated in the Commission's Rules and Regulations. See 47 C.F.R. $\S 73.1910$ (1983). This occurred in 1978. See Notice of Inquiry, 49 Fed. Reg. 20,317, 20,317 n.1 (1984) [heremafter cited as Fairness Doctrine NOI]. The roots of the doctrine are much deeper. See id. at 20,319-22. Most commentators trace its origins to a 1929 decision of the FCC's predecessor, the Federal Radio Commission. Id. at 20,319-20; see Great Lakes Broadcasting, 3 F.R.C. Annual Rep. 32 (1929), rev'd on other grounds, 37 F.2d 993 (D.C. Cir.), cert. denied, 281 U.S. 706 (1930). Subsequently, the doctrine evolved, like a common law principle, through decisions of the FCC acting on complaints or station applications. See Faimess Doctrine NOI, at 20,320. In 1949, the Commission issued a pohicy statement stating the doctrine in its present form. Report on Editorializing by Broadcast Licensees, 13 F.C.C. 1246 (1949) [hereinafter cited as Report on Editorializing]. In 1974, after a lengthy study, the FCC reaffirmed the doctrine, as a policy to be applied in disputed cases. See The Handling of Public Issues Under the Fairness Doctrine and the Public Interest Standard of the Communications Act, 48 F.C.C.2d 1, 19 (1974) [hereinafter cited as Fairness Report].

8. See Report on Editorializing, supra note 7, at 1249-50 (discussing a "long series of decisions" reaffirming this affirmative responsibility on the part of broadcast licensees).

9. The Communications Act of 1934 specifically provides that a "station license shall not vest in the hicensee any right to operate the station nor any right in the use of the frequencies designated in the license beyond the term thereof." 47 U.S.C. $\S 309$ (h)(1) (1982).

10. See, e.g., FCC v. WNCN Listeners Guild, 450 U.S. 582, 593-604 (1981) (upholding as not inconsistent with the Commumications Act of 1934 the FCC policy that reliance on the market is the best method of promoting diversity in entertainment formats); National Broadcasting Co. v. United States, 319 U.S. 190 (1943) (FCC regulation limiting hicensing of powerful networks in certain localities sustained in order to enhance competition); FCC v. Sanders Bros. Radio Station, 309 U.S. 470, 475 (1940) ("Congress intended to leave competition in the business of broadcasting where it found it, to permit a licensee to survive or succumb according to his ability to make his programs attractive to the public.").

11. See Fowler \& Brennan, A Marketplace Approach to Broadcast Reguiation, 60 Tex. L. REV. 207, 213-17 (1982) (discussing origins of concept of broadcasters as community trustees). 
manipulation of voters' values by an entrenclied, uncontrollable oligopoly motivated solely by a desire to maximize its own profits. The Fairness Doctrine, in short, not only symbolizes the trustee obligations of broadcast licensees, but also neatly encapsulates a journalistic code of ethics to which most reporters and publishers, in all media, profess allegiance. This was the view of the FCC when it explained the Fairness Doctrine in 1949:

If, as we believe to be the case, the public interest is best served in a deinocracy through the ability of the people to hear expositions of the various positions taken by responsible groups and individuals on particular topics and to choose between them, it is evident that broadcast hicensees have an affirmative duty generally to encourage and implement the broadcast of all sides of controversial public issues over their facilities . . . .12

Notwithstanding these ratlier impressive credentials as a syınbol of virtuous aspirations, the Fairness Doctrine is today under heavy assault on two fronts. The Cliairman of the Senate Committee on Commerce, Science and Transportation, which includes a subcommittee on communications, has introduced, and worked vigorously for passage of, a bill that wonld, among other things, deny the FCC power to require "an opportumity to be afforded for the presentation of any view on an issue." 13 Not content to await the outcome of that legislative imitiative, the FCC has published a Notice of Inquiry that suggests the Commission may bury the Fairness Doctrine administratively. ${ }^{14}$

12. Report on Editorializing, supra note 7, at $\mathbf{1 2 5 1 .}$

13. S. 1917, 98th Cong., 1st Sess. §4, 129 CoNG. REc. \$13,475-76 (1983) (the "Freedom of Expression Act of 1983"). The introduction of the bill by Senator Packwood and his efforts to obtain enactment are reflected throughout the hearings on the bill. See generally To Provide That The Federal Communications Commission Shall Not Regulate the Content of Certain Communications: Hearings Before the Senate Comm. on Commerce, Science, and Transportation, 98th Cong., 2d Sess. (1984) [hereinafter cited as Packwood Hearings].

14. See Faimess Doctrine NOI, supra note 7, at 1 . Whether the doctrine is mandated by the Communications Act is a matter of debate. See id. at 20,336-43. We do not address that question in this article.

The issue arises because of an ambiguous congressional action in 1959. 1mitially, the doctrine was said to rest solely on the general provision of the Act that commands the Commission to regulate in "the public interest." Id. at 20,337 (citing 47 U.S.C. $\S 303$ (1982)). In 1959, however, Congress amended section 315 of the Act, which requires that licensees afford political candidates equal time, to exempt appearances on certain news programs. Act of Sept. 14, 1959, Pub. L. No. 86274, 73 Stat. 557 (amending 47 U.S.C. $\$ 315$ ). At the same time, Congress also provided that nothing in the 1959 amendments was to be construed as "relieving broadcasters . . . from the obligation imposed on thein under this Act to operate in the public interest and to afford reasonable opportunity for the discussion of conflicting views on issues of public importance." Id.

The Supreme Court has stated that this amendment "ratified" the Fairness Doctrine. Red Lion Broadcasting Co. v. FCC, 395 U.S. 367, 382 (1969). Whether that statement is accurate and means that the Commission cannot abrogate the doctrine admimistratively is unclear. See Faimess Doctrine NOI, supra note 7, at 20,342-43; FCC v. League of Women Voters, 104 S. Ct. 3106, 3117 n.12 (1984) 


\section{A Constitutional Curiosity}

Most debates over the Fairness Doctrine begin with the same question: Does it violate the first amendment's proscription of laws "abridging the right of freedoin of speech or of the press?" The preoccupation of scholars with this question is quite puzzling. Whether the Fairness Doctrine is constitutional is a thoroughly settled issue that deserves no extended discussion. The doctrine is, or is not, constitutional depending solely on what oue means by "constitutional."

The Fairness Doctrine is obviously constitutional if one tests that assertion by asking whether a majority of the present Supreme Court, or any reasonably foreseeable variant thereof in the next decade, will declare it to be so. Without dissent, ${ }^{15}$ the Court held in the 1969 Red Lion $^{16}$ case that the Fairness Doctrine did not abridge anyone's first amendment rights. That position was reaffirmed in 1981, again without dissent. ${ }^{17}$ The chance of convincing the Court to remove the Fairness Doctrine froin the backs of multibillion dollar corporations whose principal energies are directed to packaging sex, violence, and stereotyped characters for sale to soap inanufacturers and coinputer salesmen is about the saine as the probability that the Court will give pornographers a first ainendment license to thrust lewd photographs upon unsuspecting and unwilling seventl graders.

Equally free from doubt, however, is the proposition that the Fairness Doctrine is at odds with any general principle of the purposes, values, or ineaning of the first amendinent to which the Supreine Court has subscribed in the past fifty years. ${ }^{18}$ No other Court decision over this lengthy and otherwise meandering course of history suggests any tolerance for such governmental oversight of editors' choices respecting what

(expressing no view on the legality of any action by the FCC modifying or abandoning the doctrine). See also supra note 7.

15. Justice Douglas did not participate in Red Lion but subsequently indicated that he would not have supported the decision. CBS v. Democratic Nat'l Comm., 412 U.S. 94, 154 (1973) (concurring).

16. Red Lion, 395 U.S. 367 (1969).

17. CBS v. FCC, 453 U.S. 367 (1981). Justices White, Rehnquist and Stevens dissented from the majority opinion, but not on constitutional grounds. Id. at 397-419.

18. Leaving aside for a moment the unavoidable comparison with Miami Herald Publishing Co. v. Tornillo, 418 U.S. 241 (1974), the contrast with New York Tines v. Sullivan, 376 U.S. 254 (1964), is especially striking. In New York Times, the Court greatly limited a public figure's right to sue a media defendant for defamation, in the interests of preserving the defendant's broad freedoin to exercise its first amendnent rights. See id. at 277-80 ("actual malice" requirement imposed because the fear of civil hability imposes too great a bnrden on the newspaper's exercise of first amendment rights). Powe, "Mass Speech" and the Newer First Amendment, 1982 SuP. CT. REv. 243, chronicles the unsuccessful attempts to transport Red Lion into the campaign finance cases, an area where advocates supporting government laws limiting giving and spending typically have attempted to rely on Red Lion's theory to support their cases. 
topics and views they will publish. In Red Lion, the Court simply served up soine trivial and irrelevant observations about broadcasting, sprinkled in some novel and ridiculous statements about the underlying purposes of the first amendment, and then pronounced these constitutional curiosities to be justifications for rejecting a first amendment challenge to the Fairness Doctrine. For example, the Court cited the fact that "there are substantially more individuals who want to broadcast than there are frequencies to allocate." 19 The triviality and irrelevance of the observation that scarce resources are scarce become clear when one substitutes for the words "broadcast" and "frequencies" in the Court's statement, words such as "publislı" and "newsprint," or "make movies" and "film footage," or "write letters" and "stamps." 20 That it costs money, that is, consumes a scarce resource, to speak has never before or since in first amendment jurisprudence been said to justify imposing a fairness doctrine on the speaker.

Alternatively, or additionally, the Red Lion opinion suggests that the Fairness Doctrine is constitutional because it protects "the riglit of the public to receive suitable access to social, political, esthetic, moral, and other ideas and experiences." 21 No principle could be more at odds with the bulk of first amendment jurisprudence, for it would justify any governmental rule that told a speaker what to say on the ground that the governinent lad determined the public should hear it. The astonishing breadth of the principle that control over utterances may be constitutionally justified by a public riglit to hear what government regulators determine listeners do or should prefer is tempered, thankfully, by the fact that the Court lias never relied upon that principle in resolving any other issue outside the realm of commercial speech.

At other places, the Red Lion opinion wraps the Fairness Doctrine in the inantle of antimonopoly policy. "It is the purpose of the First Amendment to preserve an uninhibited marketplace of ideas $\mathrm{m}$ which trutl will ultimately prevail, rather than to countenance monopolization of that inarket, whether it be by the Government itself or a private licen-

19. 395 U.S. at 388.

20. One might argue that the present finite number of broadcast channels renders this analogy inapt. However, given the size of the electromagnetic spectrum and given the current state of technology, many more broadcasters could be assigned frequencies. This suggests that, were demand high enough-that is, if people who "want to broadcast" were willing to pay enough-frequencies could be assigned to them. If people who wish to publish a newspaper are willing to pay for newsprint, they may do so; any difference between newsprint and broadcast frequencies is thus one of degree, not of kind. See, e.g., Freedom of Expression: Hearings Before the Senate Comm. on Commerce, Science and Transportation, 97th Cong., 2d Sess. 10-13 (1982) (statement of Solomon J. Buchsboum, Executive Vice President, Bell Telephone Laboratories).

21. 395 U.S. at 390. 
see."22 Without the doctrine's constraints, broadcasters would "snuff out the free speech of others." 23 That monopoly and free speech are incompatible is true; that the Fairness Doctrine has any relation to antimonopoly pohicy is false. If a speaker, by speaking, monopolizes and thereby snuffs out others' speech, then an uninhibited marketplace of ideas can be attained only by total silence.

But one need not resort to the intemperate criticisms found in law journals to compile a hist of the errors of Red Lion. In the 1974 Miami Herald Publishing Co. v. Tornillo ${ }^{24}$ case, the Court itself persuasively provided a point-by-poimt refutation of Red Lion. ${ }^{25}$ Tornillo invalidated on its face a Florida statute that granted pohtical candidates a right to equal space to reply to criticisms and attacks by a newspaper. The first amendment, according to Tornillo, teaches that a government "compulsion to publish that which " "reason" tells [editors] should not be pubhished' is unconstitutional. A responsible press is an undoubtedly desirable goal, but press responsibihty is not mandated by the Constitution and like many virtues it cannot be legislated." 26

How did the Tornillo Court reconcile Red Lion? By ignoring it: Red Lion is nowhere cited in Tornillo. Does that perhaps suggest Red Lion may be ripe for overruling? Certainly not: Red Lion survives Tornillo because the forner deals with broadcasting. ${ }^{27}$ So spoke the

22. Id.

23. Id. at 387 (citation omitted).

24. 418 U.S. 241 (1974).

25. Id. at $256-58$.

26. Id. at 256. One line of first amendment decisions bears a superficial similarity to Red Lion. The Court has occasionally held that the first amendment compels government to grant speakers access to government property to express their views. See, e.g., United States v. Grace, 461 U.S. 171, 176-77 (1983) (declaring unconstitutional a statute prohibiting the carrying of any flag, banner, or device on Supreme Court grounds). This principle has also been extended to company-owned towns. See Marsh v. Alabama, 326 U.S. 501, 508-09 (1946). Further, the Court has held that a state may require that a privately-owned shopping center, to which the public is invited, aceord some rights of access to citizens seeking to exercise free speech and petition rights. See Pruneyard Shopping Center v. Robims, 447 U.S. 74, 80-88 (1980).

In fact, however, these cases are inapposite. In none of them was the owner of the property compelled to express any particular views himself or to edit his own statenents. Like the Florida statute in Tornillo, these cases only made property owners relinquish some property rights, not subject their own editorial choices to governmental regulation. Tornillo thus involved a less drastic invasion of the editor's first amendment interests than Red Lion. Curiously, the Supreme Court that decided Red Lion also took the view that the Communications Act of 1934 prohibits the FCC from requiring that speakers be granted access to broadcast facilities not licensed to them. See FCC v. Midwest Video Corp., 440 U.S. 689, $702-09$ (1979).

27. Possibly the most interesting contrast between Red Lion and Tornillo is the Court's view of whether the existence and application of the law at issue will have a chilling effect on the decisions of the media. Red Lion stands on the conclusion that the Fairness Doctrine will not chill broadcasters-and that if it does it should be enforced nore rigorously to warm them up. If the Fairness Doctrine that exists in its supporters' mind does not chill broadcasters, they are a pretty hardy breed 
Court in $1981 .{ }^{28}$ Does that make any sense? No. Indeed, this is where we came $\mathrm{m}$. The Fairness Doctrine is, or is not, clearly constitutional depending solely on what one means by "constitutional."

\section{AN IMPOSSIBLE DREAM}

The foregoing expresses, in summary form, our reasons for believing that respect for established, widely-shared first amendment values, sucl1 as those reflected in Tornillo, compels the conclusion that the Fairness Doctrine should be discarded. Indeed, the constitutional case against the doctrine is as elementary as it is overwhelming. But that is not our principal point. The fact of the matter is that, wholly apart from first amendment considerations, the Fairness Doctrine does not, will not, and cannot work. And that is our principal point. At best, the Fairness Doctrine is, like the 1962 New York Mets, a glorious but futile symbol, full of wondrous pretension and promise, yet utterly devoid of performance.

As a practical matter, the Fairness Doctrime is a failure for two distinct reasons. First, viewed as an exercise of regulatory power, there is no reason to believe that the doctrine achieves its purposes or does so in an efficient manner. ${ }^{29}$ Second, as a legal principle it is utterly meaningless. ${ }^{30}$ In our view, these practical considerations are sufficiently compelling that, even were the constitutional issues more nearly balanced on both sides, the case for abolishing the Fairness Doctrine would be clear.

\section{A. The Fairness Doctrine as a Regulatory Policy.}

Perhaps, once upon a time, regulation was valued for its own sake. To test the merits of a regulation one asked only whether it directed

and should be compared to their distant cousins, garden-variety timid newspaper editors, who, if faced with something like the Fairness Doctrine, would be frozen. Such at least was the teaching of Tornillo. One nced not have spent time in newsrooms in the respective industries to know that the Supreme Court is not discussing anything that one would recognize as the United States. Consider the comments of NBC News' Bill Monroe, a reporter who has spent time in newsrooms in each industry:

Some years ago as a young man I worked for a newspaper. I was very impressed with the spirit of independence on the part of the editors of the newspapers. They didn't care if something they pnt in the paper offended a major political figure. Later I went to a television station and slowly I discovered that the managers of the television station were a little afraid of government. They were timid, conscious of government looking over their shoulder in a way that the newspaper publisher and editor for whom I had worked lad not been.

Freedom of the Press, in AMERICAN ENTERPRISE INSTITUTE ROUND TABLE 58-59 (July 29-30, 1975). See also The First Amendment and Broadcasting: Press Freedoms and BroadCAST JoURNALISM 30-31 (H. Rımdell \& J. Heuterman eds. 1978) (transcription of 1978 Edward R. Morrow Symposinm; statement of Bill Monroe).

28. See CBS v. FCC, 453 U.S. 367, 396 (1981).

29. See infra notes $31-70$ and accompanying text.

30. See infra notes 71-99 and accompanying text. 
someone to do something that, if done, comported with the public interest. By such standards, as we observed at the outset, the Fairness Doctrine would receive high marks. So, of course, would a regulation telling restaurants to provide fast, clean, cheap service in comfortable surroundings. Yet, it is difficult to believe that anyone would assess the merits of such a regulation today without also measuring its practical effects, its costs, and the costs and effects of alternative methods of achieving the goals of the regulation. By such standards, the Fairness Doctrine appears to be an unjustified method of achieving its laudable goals.

Those goals, of course, are to encourage full and fair coverage of controversial issues. They reflect a desire to mold the behavior of both broadcasters and their audiences. For the latter, the Fairness Doctrine represents a governmental policy that citizens ought to be well-inforıned even if that is not a priority of the citizen. For the former, the Fairness Doctrine sets forth a standard of conduct to be followed in the operation of the station, although it is obvious that achieving the goals of the doctrime will be accomphished, to some extent, witlout any Fairness Doctrime. A station with news programs will introduce viewers or listeners to soine facets of public controversies simply by reporting the main events of the day. Furthernore, journalistic ethics will cause some reporters and news programs to be scrupulously fair as a matter of professionahism. The Fairness Doctrime is aimed at those stations that would avoid controversy, or air biased or misleading programıning. At this point, the apparently complementary goals of the doctrine push in opposite directions in practice. If the issues treated are in fact controversial, then viewers and listeners may be more sensitive to whether or not the treatment is fair. If controversy is avoided no such problems occur. Because it turns out that there is no penalty, because there is no enforcement, for failure to cover controversy, ${ }^{31}$ broadcasters can-and everyone agrees some $\mathrm{do}^{32}$-avoid soine fairness problems simply by not offering programming on some issues. ${ }^{33}$ Furtler, once a station does decide to

31. The Commission has only once held a broadcaster to have violated the obligation to cover controversial issues. See Mink v. WHAR, 59 F.C.C.2d 987, 997 (1976) (Clarksburg, W. Va. radio station violated Fairness Doctrine by failing to cover the issue of strip mining); see also Fairness Report, supra note 7, at 10 ("we have no intention of becoming involved in the selection of issues to be discussed, nor do we expect a broadcaster to cover each and every important issue which may arise in his community").

32. See, e.g., Fairness Doctrine NOI, supra note 7, at 20,332, and sources cited therein.

33. See, e.g., Freedom of Expression: Hearings Before the Senate Comm. on Commerce, Science and Transportation, 97th Cong., 2d Sess. 123, 127 (1982) (statement of Bill Monroe):

It seems clear to me that many station owners and their managers, though they might not wish to admit it, feel that their commercial lives depend on minimizing controversy. Broadcasters do not feel free to follow their own consciences as journalists because they have to answer to a bureaucratic conscience, with its close-packed pages of rules, regula- 
broadcast some programming dealing with a controversial issue, it can determine largely as it pleases how much should be devoted to the differing viewpoints and who and what materials to use in presenting each side. In order to reduce the need for close and sustained agency supervision of broadcasters, the Commission has built into the doctrine a remarkable alnount of broadcaster discretion. ${ }^{34}$ As a result, surprisingly hittle balance is necessary to meet the obhigation to cover all sides of an issue.

This, in brief, is the Fairness Doctrine about which so many accolades are heard. But its proponents often do not argue in favor of the doctrine just described. Enainored with its goals, they praise a doctrine that does not exist. In our experience, defenders of the Fairness Doctrime fail to address the question whether practicalities of admimistration and enforcement limit the sweep of the goals of the doctrine. Fairness Doctrine proponents consistently (1) mischaracterize its effects; ${ }^{35}$ (2) ignore its costs; ${ }^{36}$ and (3) overlook the availability of competition as an alternative. ${ }^{37}$ To the critical observer, then, the doctrine is an unduly expensive regulatory venture whose real world effects inay well be to produce results at odds with its own asserted purposes.

1. Mischaracterizing Effects. First, the Fairness Doctrine is often explained as one that compels fairness or access by neglected groups by substituting viewers' choices regarding what they wish to hear or see for broadcasters' decisions as to what to broadcast. This was a principal reason advanced by the Supreine Court for upholding the doctrine in Red Lion. ${ }^{38}$ The Fairness Doctrime, in fact, does no such thing. Instead of substituting viewer or citizen control for broadcaster control of programming, to the extent the doctrine works it substitutes monohthic governmental choice for the programs that otherwise would result from broadcasters' competition for viewers' and histeners' time and attention. Its proponents mischaracterize the operation of the doctrine and the system of program selection that would prevail in its absence.

When fairness regulations are enforced, no deity or Platoric Guardian determines whether a program is fair. That decision is made in the

tions, and precedents. So the electronic media, by contrast with what the first amendment intended, are stifled and stunted.

34. See, e.g., Fairness Report, supra note 7, at 10-17. "We beheve that the public is best served by a system which allows individual broadcasters considerable discretion in selecting the inanner of coverage, the appropriate spokesmen, and the techniques of production and presentation." Id. at 16.

35. See infra notes 38-45 and accompanying text.

36. See infra notes 46-64 and accompanying text.

37. See infra notes 65-70 and accompanying text.

38. See Red Lion, 395 U.S. at 389-90. 
first instance by a government attorney in the FCC's Mass Media Bureau -an attorney so publicly unaccountable that his or her name or title will not even appear on an FCC orgamization chart. That individual is, of course, following a more or less coherent set of publicly reviewable guidelines. ${ }^{39}$ She may be responding to the complaints of a few listeners or viewers, but "the public" whose interests are being enforced is one that exists in that attorney's-or her bosses'-eyes, and its listening and viewing preferences have never been systematically canvassed-much less proven to be uniform-by the FCC. ${ }^{40}$

Conversely, were there no fairness regulations, the most a broadcaster could hope to gain from misniforming or misleading its listeners is the allegiance of those already ideologically committed to the broadcaster's point of view. That allegiance, probably depending on the issue addressed, may or may not counterbalance the loss of viewers who are not ideologues. ${ }^{41}$ But, in the absence of the doctrine, broadcasters would have almost no incentive to provide erroneous or one-sided information to those who do not want it or to refuse all coverage of issues that interest many viewers or histeners. They do, after all, have to convince someone to turn on the set and tune im their frequency. 42

To the extent that the doctrime has practical effects, it is as likely to avoid the appearance of one-sided presentations as to compel fairness. Although the regulation purports to require that some minimal coverage be given to large public issues, that aspect has proven unmanageable and, with a simgle exception in its entire history, unenforceable. ${ }^{43}$ The Fair-

39. See FCC, The Law of Political Broadcasting and Cablecasting: a Political PRIMER 69-71 (1984) (outlining the requirements of the Fairness Doctrine within the context of political broadcasting).

40. See Fairness Report, supra note 7, at 8. ("[W]e [the FCC] do not monitor broadcasts for possible violations, but act on the basis of complaints received from interested citizens. These complaints are not forwarded to the licensee for his comments unless they present prima facie evidence of a violation.").

41. For example, we assume relatively few people have a firm ideological belief respecting the causes of federal budget deficits. If we are correct, then broadcast coverage that points to rising interest rates as the sole cause of deficits will harm the station's ratings more than it will help them. We also assume that most people beheve incest should be a criminal act. If that assumption is correct, then crusading for the retention of criminal penalties for incest-without covering the alternative views that criminal sanctions for intra-family conduct are difficult to apply fairly and that at lcast consenting adults should have wider personal liberty-is unlikely to drive many listeners away. See also infra note 42.

42. The doctrine may, then, require the committed ideologue not to air one-sided presentations to similarly committed ideologues. If, indeed, the doctrine is supposed to protect the rights of listeners and viewers, this is a very curious result. Such communications may offend persons who do not agree. See infra notes 86-97 and accompanying text for discussion of WXUR case. Those persons need not tune to the station, however, for-unlike newspapers-radio and television outlets are relatively plentiful in nost communities.

43. See supra note 31 and sources cited therein. 
ness Doctrine does not identify specific programs that should be broadcast and require broadcasters to do so. Virtually all the doctrine commands is that a broadcaster that does one thing-for example, broadcasts a program on oil production-must also do another-for example, include in that program, or another, the view that oil production is controlled by a doinestic cartel and the view that it is not controlled by a cartel. Consistent with the Fairness Doctrine the broadcaster can always choose not to do the first thing. In such case, of course, neither the broadcaster nor the regulation furthers any public interest.

Furthermore, even when the broadcaster airs a program witl seemingly balanced coverage, what is fostered may well be more the illusion of fairness than a genuine exploration of positions. The Fairness Doctrime speaks in terms of balanced coverage-presenting both sides of controversial issues. In a typical contested coinplaint, the broadcaster will be charged with presenting only one side of an issue and ignorimg the other side. ${ }^{44}$ This inethod of applying the doctrime can have a perverse impact in light of the reality that many of the inajor controversial issues of our time are multi-sided. Because of a tendency to think im terms of twosided issues, it is not surprising that many are characterized as the "Republican" side and the "Democratic" side.

For example, in the early 1970's a group on the Republican right pressed a major fairness coinplaint. 45 That group argned that its very hawkish positions on national security issues were being virtually ignored; the debate in issue was telecast as if the only clioices were those of the Democratic left and the Nixon administration. Altliough the Commission and a reviewing court decided the case adversely to the complainants on a different ground, the complaimt could just as easily liave been disposed of on the ground that the network had in fact provided a full and fair discussion of national defense by putting forward the dominant positions of each of the two major parties. It should also be noted that during this period the views of the inore liawkish Deinocrats were underplayed as well.

What this illustrates is the very real risk that the minority positions of the inajor parties will be ignored even as the broadcasters remam in full compliance witl the Fairness Doctrime. The viewpoimt of the dominant Democratic faction is presented and countered not by the minority view within the Democratic party, but by the view of the dommant faction within the Republican party. This practice usually will satisfy the Fairness Doctrine while providing no coverage to the views of those with

44. See, e.g., the cases discussed infra in notes 71-97 and accompanying text.

45. See infra notes 71-74 and accompanying text for discussion of the $A S C E F$ case. 
nonmainstreain positions. Enforcing the Fairness Doctrine in this inanner will provide some information, although largely the type that would be offered in the absence of any legal compulsion, but does not require that broadcasters seek out views that do not dominate traditional debates.

Properly viewed, then, the Fairness Doctrine substitutes potential bureaucratic control of programming for the operation of the inarketplace with a principal end of avoiding the appearance of biased prograinming concerning controversial issues. It does not force or even encourage broadcasters to give citizens information for which they have expressed a desire, nor does it provide broadcasters an incentive to seek out unconventional views.

2. Ignoring Costs. Proponents of the Fairness Doctrine not only misrepresent its effects but also appear to ignore its costs. In fact, like any other regulation, the Fairness Doctrine imposes costs of enforceinent on the governinent and of comphance on those subject to it-here, broadcast licensees. What are these costs?

The effects on licensees are easiest to assess. Unless the doctrine is totally unenforceable, it imposes costs on those subject to it. As we have just observed, lowever, broadcasters can avoid these costs by clioosing to be silent on controversial issues or to offer programs that offend no one. By itself, then, the Fairness Doctrime makes more attractive to broadcasters the option of self-censorship on controversial issues. It is as though the FCC liad imposed a tax on reporting matters of public debate.

It may not mean much to NBC to have a fairness complaint pending for a year stemming from a charge that its 1978 mini-series "Holocaust" violated the doctrime by failing to provide a reasonable opportunity to present the view that there was no "German pohicy of Jewish exterinination during World War II."46 The same caimot be said for allegations that are not absurd on their face or for stations that lack network clout. Consider KHOM in Houma, Louisiana which, like so many stations prior to 1980 , carried Ronald Reagan's radio commentary program. ${ }^{47}$ In the first eighteen months the station aired the program it did not receive a single coinplaint from anyone in its listening area. But the airing of one program produced letters from nine individuals and groups outside the Houma area claiming they were entitled to free time to respond. KHOM spent time reviewing the tape, and unable to decide whether there had been personal attacks, consequently paid its "tax" to a Washington law-

46. In re Application of NBC for Renewal of License of Station WNBC-TV, 71 F.C.C.2d 250, 251 (1979).

47. Packwood Hearings, supra note 13, at 125 (statement of Raymond Saadi, station KHOM). 
yer who advised the station to provide the free air time to those claiming it. ${ }^{48}$

More significant were the costs to station KREM in Spokane and to its general manager, Eugene Wilkin. ${ }^{49}$ In defending an on-the-spot decision not to allow representatives claiming to speak for all environmentalists to respond to an editorial favoring Expo 74, the station ran up legal fees of over $\$ 20,000$, spent 480 hours of executive time, and endured a delay in license renewal. ${ }^{50}$ Wilkin was branded as "controversial" and his broadcast management career was ended. ${ }^{51}$ Why? The four individuals who claimed to represent all of Spokane's environmentalists were representatives of eight neighbors who had broken off from the city's major environmental organization to form their own ad hoc committee. Wilkin saw them only once, on the day he asked for verification that they did, in fact, represent all environmentalists. On that day they responded, "We'll be back with that."52 They misspoke: Instead of "that" they came back with the FCC and a full field investigation of the station. ${ }^{53}$

Whether or not these are isolated cases, they are known to the closely-knit mdustry. The costs varied from a hittle above de minimis for NBC, to modest for KHOM, to expensive for KREM, to incredibly high for Eugene Wilkin. But the very fact that there are costs and the costs can be significant, generates incentives to avoid them. Other factors, such as competition from other media, may force broadcasters to cover controversial issues and to present various viewpoints about them. Nevertheless, to the extent it has its own impact, the effect of the Fairness Doctrine is quite the opposite.

The only way to avoid this result would be to enforce the Fairness Doctrine so thoroughly that hicensees could not escape this "tax," but would be forced to "pay" it. Given the proven impracticality of defining what issues must be covered, ${ }^{54}$ this seems an implausible option. Even if that hurdle conld soinehow be overcome, when one compares the extent of programming covered by the regnlation to the resources available to the FCC, one must wonder what the Fairness Doctrine could plausibly achieve. At the end of 1983,8216 commercial radio stations and 870

48. Id. at $125-26$.

49. See In re Sherwyn Heckt, 40 F.C.C.2d 1150 (1973).

50. H. Geller, The fairness Doctrine in Broadcasting: Problems and Suggested COURSES OF ACTION 41-42 (1973).

51. See Packwood Hearings, supra note 13, at 227-28 (statement of Eugene Wilkin).

52. Id. at 228.

53. See id. at 227.

54. See Mink v. WHAR, 59 F.C.C.2d 987, 997 (1976), the single instance where the Commission has found a broadcaster to have violated the obligation to cover controversial issues, and Fairness Report, supra note 7 , at 10 , as evidence of this impracticability. 
commercial television stations were operating in the United States. ${ }^{55}$ If, on average, each of these broadcasts a total of sixty minutes of news a day, that would yield 9086 hours per day of news programming that must conform to the Fairness Doctrine. That amounts to the equivalent of 39,796,680 five-minute newscasts per year nationwide. ${ }^{56}$

Performing this herculean enforcement task is the FCC, with a total budget in recent years of around $\$ 90,000,000.57$ Of course, not all of these funds or all of its employees are available to enforce the Fairness Doctrime. Among its other duties, the FCC not only manages the entire electromagnetic spectrum but also regulates all interstate telephone and telegraph service, all American commumications satellites, and all the technical operations of its broadcast hicensees. At present, the Commission also has pending 16,000 applications for multi-channel, multi-point distribution system permits, and over 12,000 applications for low-power TV stations. ${ }^{58}$

These data do not reveal precisely how much time and resources the Commission can direct to Fairness Doctrine issues. Surely, lowever, they demonstrate that any enforcement scheme must select very few targets for investigation, ${ }^{59}$ and consequently, must operate oblivious of the kind and quality of informational programming generally being broadcast throughout the Umited States. ${ }^{60}$ Further, the FCC las no pro-

55. Broadcasting/CABlecasting YearbooK 1984 at A-2.

56. Not all newscasts will be unique, for some stations will broadcast identical network programming during some or all of their news periods.

57. See Standing Pat, Broadcasting, Dec. 17, 1984, at 7.

58. Report and Order in the Matter of the Amendnent of $\S 73.3555$ of the Commission's Rules, 49 Fed. Reg. 31,877, 31,881 (1984).

59. See Fairness Report, supra note 7, at 8. ("As a matter of general procedure, [the Comnission does] not montor broadcasts for possible violations, but act[s] on the basis of complaints received from interested citizens."). See also infra note 61.

60. James McKinney, Chief of the FCC's Mass Media Bureau, explained how the FCC actually examines fairness complaints:

It's been said that it's not a good idea to watch how legislation or sausage is made. And I want to raise a new issue with you here today because I don't think it's very pleasant to understand how Fairness Doctrine complaints are adjudicated. But it might be interesting for you to know the process we go through here at the agency, at the lower staff level before the Commissioners get it for a final decision.

We in fact sit down with tape recordings, with videotapes of what is being broadcast, what has been broadcast on a specific station. We compare that to newspapers and other public statements that are made in the community. We try to make a decision as to whether the issue is controversial and whether it is of public importance in that conmunity which may be two thousand miles away. And when it comes down to the final analysis, we take out stopwatches and we start counting seconds and minutes that are devoted to one issue compared to seconds and minutes devoted to the other side of that issue. All of that is done by people here in Washington who work for ne, who may have never been a journalist in their life, many of whoin are attorneys. But in the final analysis we start giving our judgment as to what words inean in the context of what was said on the air, what was the twist that was given that specific statement or that commercial advertisement, was it really pro-nuclear power or was it pro some other associated issue. Given that 
gram for systematically momitoring compliance witl the Fairness Doctrine or for randomly targeting stations for investigation at the FCC's initiative. ${ }^{61}$

That a rule seeks to govern many transactions or episodes does not necessarily inean it lacks bite. Consider, for example, the antitrust proscription against price-fixing or the criminal law prohibition of sloplifting. The Fairness Doctrine, however, is particularly likely to be dependent for its efficacy on the governmental resources devoted to it; because the doctrine does not provide clear standards for distinguishing between legal and illegal conduct, ${ }^{62}$ only the FCC can tell whether a violation occurs. For the same reason, penalties for noncompliance are not severe. The Commission could scarcely justify revoking a hicense for conduct that was not clearly illegal when undertaken. Finally, no private enforceinent of the Fairness Doctrine is autliorized. These factors suggest that only repeated, egregious violations of the doctrine by an especially visible licensee are likely to result in substantial penalties. Moreover, proscriptions agamst price-fixing and shoplifting do not in theinselves generate incentives to avoid the purposes the rules seek to promote-incentives that thereby increase the difficulty of enforcement. The Fairness Doctrine gives licensees a substantial incentive to avoid its purpose of informing the public about controversial issues. A prohibition on slioplifting does not make stealing merchandise more attractive.

Perhaps the imbalance between enforcement resources and enforcement responsibilities means the Fairness Doctrine is a lrollow command. More plausibly, it means the doctrine has substantial force only for the most visible broadcasters-the three dommant television networks and their affiliated station licensees. ${ }^{63}$

An assessment of the effects and costs of the Fairness Doctrine paints a gloomy portrait indeed. For control by inarket forces the doctrine substitutes governmental control over programming, largely to attain the end of avoiding the appearance of one-sided presentations. The principal effect of the regulation is to reduce stations' incentives to broadcast controversy over public issues. This effect, iromically and thankfully,

kind of governmental review, does that change anyone's mind as to the chilling effect of having government involved in the process?

J. McKinney, Remarks at FCC Faimess Doctrine Hearings (Feb. 8, 1985) (transcript of audio recording on file with Duke Law Journal).

61. See Fairness Report, supra note 7, at 8. Curiously, the Commission asserts that the fact that it examines very few broadcasts and does no systematic moritoring or targeting for comphance review are reasons to retain the rule. Id. at 7-8. The position expressed in the Fairness Report seems to be that the Faimess Doctrine is an acceptable regulation because it does not noticeably affect licensees.

62. See infra notes 71-99 and accompanying text.

63. But see the case studies cited infra at notes 71-97 and accompanying text. 
is mitigated by the FCC's apparent mability, given its limited resources, to enforce the doctrine except randomly or against the most visible broadcasters. ${ }^{64}$

We have yet to discover a defense of the Fairness Doctrine that takes account of its practical effects and costs. Were such a defense attempted, however, it would ouly begin the analysis, not end it. For the question would remain whether a more practical and effective method is available to achieve the goals of the Fairness Doctrine. In failing to consider whether preferable alternatives exist, proponents of the Fairness Doctrine commit a third error.

3. Overlooking Alternatives. Competition among broadcasters for viewers' time and attention is at least as likely as enforcement of a Fairness Doctrine to serve the laudable public interests for which the doctrine was developed. ${ }^{65}$ Unless radio and television are unique among all media of mass commumications, the evidence that competition will work satisfactorily is overwhelming. Sometimes presentations in other media provide balanced coverage of all sides of controversial issues. Other

64. The FCC has been quite proud of its limited enforcement role. The 1974 Fairness Report pointedly noted: "Thus broadcasters are not burdened with the task of answering idle or capricious complaints. By way of illustration, the Commission received some 2400 faimess complaints in fiscal 1973, only 94 of which were forwarded to licensees for their comments." Fairness Report, supra note 7, at 8. Only seven of these resulted in findings of violations. As then-Commissioner Glen Robinson observed two years later, the small number of adverse findings can only be the result of three things-(1) incredible fairness, (2) remarkably imeffective enforcement, or (3) a standard of licensee discretion so broad almost anything will stand-and he seriously doubted the first. In re The Handling of Public Issues Under the Fairness Doctrine and the Public Interest Standards of the Communications Act, 58 F.C.C.2d 691, 710 (1976) (Robinson, Comm'r, dissenting).

65. There have been two major alternatives to the Fairness Doctrine considered over the last decade. One is some form of open access and the other is Henry Geller's 10-issue listing. Like the FCC, we believe neither is particnlarly apt for obtaining either lively debate or coverage of important issues.

Access proposals in one form or another have been made since Red Lion. See especially the literature cited supra, note 3. While we see much that is desirable in a station adopting an access policy, nothing in any of the proposals assures that any particular issues will be covered. Although the example seems unbelievable on its face, a San Francisco station with an access policy received but three access messages relating to Watergate or the impeachunent controversy between December 1972 and Richard Nixon's resignation. In re The Handling of Public Issues Under the Fairness Doctrine and the Public Interest Standards of the Communications Act, 74 F.C.C.2d 163, 174 (1979). We cannot guarantee that a station would use its own time better than that time would be used if delegated to others, but the likelihood of better use by the station, which is, after all, in the programming busmess, is quite high.

The Geller ten-issue proposal calls for a post hoc determination by each station of what were the ten most significant issues it covered during the prior year and a listing of representative programming on these issues as well as the partisan spokespersons who addressed them. The proposal is a wonderful opporturity for complainants to second-guess the station on covering the wrong issues or the right issues with the wrong people. The FCC rejected it as little more than an additional paperwork requirement, $i d$. at 179 , an analysis that appears apt. 
times they do not. In all cases, however, the satisfactory answer has been, and continues to be, to rely on competition to produce the full story.

For example, no regulation required that the film "The China Syndroine" adequately portray all views on the risks of melt-downs in nuclear power plants. No law required that the Washington Post fully cover the election of ineinbers of the District of Columbia convention to draft a state constitution. No federal rule provided that the publishers of Richard Nixon's Memoirs include a balanced summary of George McGovern's campaign platform. No government agency saw to it that rebuttals be delivered on behalf of individuals parodied in Gilbert and Sullivan operettas. These and countless other flagrant "violations" of the "fairness doctrine" did not go ulmoticed, ${ }^{66}$ but neither were they occasions for imposing a fairness obligation on these other inedia. Films, newspapers, books, hive theater-and all other media except radio and television-flourish under a regime thiat eschews governmental assurance of fairness for the results generated by popular choice among competing voices.

Nor is there any reason to believe that radio and television are umique in any relevant way. Neither has any peculiar ability to distort information. Neither is sheltered from competition witli otler media in a way that those others are not. It imight be contended that the three dominant television networks are effectively protected against competition froin other television sources. That has been true in the past, ${ }^{67}$ but will not be so in the future.68 Furthermore, the previous insulation of the $\mathrm{ABC}, \mathrm{CBS}$, and NBC networks derived from a series of governmental regulations, many of which have been reversed, that rest on no enduring public interest policy. ${ }^{69}$ Thus, if television network concentration is the rationale for the Fairness Doctrine, no public policies would be disserved by clroosing to deconcentrate networking rather than to promulgate the Fairness Doctrime.

66. See, e.g., Schrag, By The People: The Political Dynamics of a Constitutional Convention, 72 Geo. L.J. 819, 848 (1984) (noting that the Washington Post carried but a single story on the campaign for delegates to the D.C. constitutional convention).

67. See S. Besen, T. Krattenmaker, A. Metzger, \& J. Woodbury, Misregulating Television: Network Dominance aNd THE F.C.C. 4-17 (1984) (pointing to entry barriers imposed by governmental regulation as protecting network dominance).

68. See id. at $\mathbf{1 7 - 2 0}$ (predicting a substantially different competitive environment by the end of the decade due to relaxed regulatory barriers).

69. See id. at 168-73 (criticizing present regnlatory policies as harmful). See also Besen \& Krattenmaker, Regulating Network Television, Regulation, May/June, 1981, at 27-34 (cliaracterizing FCC policies as "mis-regnlation" and concluding that "tlie FCC spent over thirty years adopting doubtful solutions based on dubious premises"). 
Finally, to revert to the constitutional theme, competition as a method of achieving fairness coinports more squarely with the policies underlying the first amendinent. As the Supreme Court explained it, in a non-broadcast context:

The constitutional right of free expression is powerful medicine in a society as diverse and populous as ours. It is designed and intended to remove governmental restraints from the arena of public discussion, putting the decision as to what views shall be voiced largely into the hands of each of us, in the hope that use of such freedoin will ultimately produce a more capable citizenry and inore perfect polity and in the belief that no other approach would comport witl the premise of individual dignity and choice upon which our political system rests. ${ }^{70}$

We fail to see how proponents of the Fairness Doctrine can square their position with this view of the policies underlying the first annendinent.

4. Summing Up: Net Effects of the Fairness Doctrine. A mathematical calculation of the costs and benefits of the Fairness Doctrine is not feasible. Rudimentary figures for such an exercise, including the average amounts of news coverage or broadcast time in various media and the costs of different methods of news gathering and disseminating, are not routinely available. Such a calculation, in any event, probably would be beside the point. The purpose of the doctrine is to produce a quality of reporting - balanced and fair-that is not quantifiable and whose beneficial effects are subtle and occur over very long periods of time.

This should not preclude, however, a generalized assessment of the utility of the Fairness Doctrine as a tool for regulating radio and television. When one considers critically the probable effects of tlie doctrine, its public and private costs, and the results that can be achieved by relying on alternative and cost-free techniques, the doctrine's principal net effects appear to be: (1) to foist upon broadcast hicensees the FCC's view of what are important positions on public issues, and (2) to reduce incentives among broadcasters to compete for listeners' and viewers' attention by offering programs that address controversial issues. To the extent that these effects are not realized, this is due to the fact that (1) systematic monitoring of comphance with the Fairness Doctrine is impossible, given the relative size of the industry and resources of the agency; and (2) competition with other media for the public's attention and trust are likely to force broadcasters to cover many sides of significant public issues. At best, then, it is difficult to grasp how anyone who shares the goals purportedly sought by the Fairness Doctrine can argue that we are better off with it than without it.

70. Cohen v. California, 403 U.S. 15, 24 (1971). 


\section{B. The Fairness Doctrine as a Legal Principle.}

1. The Problem. Those who remain unpersuaded that the Fairness Doctrine is an ill-advised-indeed, probably counterproductiveregulatory pohicy necessarily must agree that the doctrine, if it is to work successfully, requires the government to walk a tightrope in defining that which does and does not violate the rule. If, to avoid excessive self-censorship, the doctrine apphes too loosely or infrequently, it will not achieve reasonable balance. Conversely, if the Fairness Doctrine tightly constricts all programming that might plausibly touch upon a controversial topic, it will unduly stifle creativity and generate excessively bland programs. The FCC, $m$ these circumstances, is much like Goldilocks ruminaging around the home of the Three Bears. The Fairness Doctrine camiot be too hot, too big, or too hard. Nor can it be too cold, too sinall, or too soft. It inust be just right.

Avoiding this predicanent is impossible and escaping it has proved no easier task. While attemptimg to get the Fairness Doctrine just right, the FCC and the federal courts have shown it to be, in fact, an incoherent legal principle. Four cases starkly reveal the incoherence. Three of the cases are the inajor fairness cases of the prior decade: Each resulted in an opinion by the District of Columbia Circuit. The fourth ended at the FCC. Although arguments can be made against illustration by example, we beheve that the problems of fairness enforcennent illustrated in these cases are inherent in the doctrine. We further beheve that if the Fairness Doctrine cannot solve these cases, proponents of the doctrine bear a very heavy burden of explaining just what cases it can handle and why they are sufficiently important to justify the costs of the doctrine.

\section{The Incoherence of the Fairness Doctrine Today.}

a. $A S C E F{ }^{71}$ In the mid-1970's, the American Security Council Education Foundation (ASCEF) presented the FCC with a study of CBS News' handing of "national security issues." Using four subtopics-Vietnam, American military and foreign affairs, Soviet military and foreigu policy, and Chinese military and foreign policy-as aspects of the overarching national security umbrella, ASCEF charged that CBS had violated the Fairness Doctrine by presenting stories that either supported the then-current perception that the Soviet threat was well-met by American military preparations or by presenting inforination suggesting that the Soviet threat was less serious than the Nixon administration per-

71. American Sec. Council Educ. Found. v. CBS, Inc., 63 F.C.C.2d 366 (1977), affd en banc sub nom. American Sec. Council Educ. Found v. FCC, 607 F.2d 438 (D.C. Cir. 1979). An excellent discussion of the complaint, prior to any FCC action, appears in F. FRIENDLY, ThE GooD GUYS, THE BAD GuYs AND THE F1RST AMENDMENT 167-91 (1976). 
ceived and that the United States should decrease its national security efforts. All but ignored, ASCEF alleged, was information suggesting that the Soviet threat was consistently greater than perceived and should be countered by increasing American military spending. Essentially what ASCEF charged was that on the most important issue of the time-war and peace-one television network was systeniatically feeding its viewers a distorted and unfair picture over the range of issues encompassing national security.

The FCC declined to hold a hearmg on the issue. It disnissed ASCEF's complaint for failure to present a particular, well-defined issue as the Fairness Doctrine requires. The Court of Appeals for the District of Columbia Circuit, sitting en banc, affirmed on precisely the same ground. ${ }^{72}$ Even if the coniplaint were correct, the court held, the con1plainant has a duty to present a sufficiently nianageable issue to the Coinimssion for determination. Here, the majority concluded, the issue was too big and too annorphous. Three dissenters found that conclusion ridiculous. The issue "was plain as day: whether this nation should do more, less, or the same about perceived threats to its national security."73 If the charge by ASCEF were accurate, then CBS' overly-dovish position constituted a massive fairness violation. Yet in response the niajority ducked the hard questions, "instead carving an ill-defined safe harbor into which the Commission may sail when the waters are rough." 74 Like Papa Bear's bed, the issue ASCEF presented was too big and too hard for the Fairness Doctrine.

b. $N B C .{ }^{75}$ In late 1969, NBC Nightly News carried a three-part story on air traffic safety. One of the segments contained an interview with a private pilot who had circled Shea Stadium durmg a World Series game. That same segment contained a longer interview with a senior airline pilot, a family man with years of experience flying, who authoritatively stated that the greatest danger in commercial aviation came from private pilots. The NBC reporter twice stated that the private pilots were a danger in the crowded air around major airports. Thus it was difficult to escape the conclusion that, correctly or not, private pilots had been attacked. Their trade association unsuccessfully contended that the Fairness Doctrine had been violated. banc).

72. American Sec. Council Educ. Found. v. FCC, 607 F.2d 438, 448 (D.C. Cir. 1979) (en

73. Id. at 467 (Wilkey, J., dissenting, joined by MacKinnon and Robb, JJ.) (emphasis oinitted).

74. Id. at 463 (Wilkey, J., dissenting).

75. In re NBC, 25 F.C.C.2d 735 (1970). 
The Commission agreed with NBC that the programs had been about "Air Traffic." Problems relating to private pilots and the hazards they might create constituted a sub-issue, and, although a broadcaster must be fair overall, it need not be fair on each sub-issue. Thus the case was the opposite of $A S C E F$. In $N B C$, the private pilots lost because their issue, even if controversial, was, like Baby Bear's chair, too small.

c. Accuracy in Media. ${ }^{76}$ How about a case that, like Baby Bear's porridge, is just right? That was NBC's Peabody Award-winning "Pensions: The Broken Promise." The program was a wonderful hour of prine time muckraking that focused on private pension plans in the era immediately before federal regulation. Although the moderator, Edwin Newinan, made an obligatory bow to the fact that not all private pension programs liad faults, the dominant theme of the program was that a great many einployees who were anticipating a mice pension in retirement would find they liad none. Case history after case history was examined: bankruptcy, nonvesting pensions, inadequate set-aside. As Newinan said in conclusion: "The situation, as we've seen it, is deplorable."77 Accuracy in Media thought NBC had done a hatchet job on private pensions. One need not be an ideological critic to note that the muckraking style of the program was designed to show a serious problem without wasting time on those pension plans that were in good shape.

NBC's lawyers liandled the problem by belittling the program's purposes and achieveinents. Instead of "Pensions: The Broken Promise," the lawyers characterized it as "Pensions: Some Broken Promises," a program about the rather mundane topic of "some of the probleins involved in some private pension plans."78 To the rejoinder that they were not describing the program that NBC aired nor one that would wim a Peabody, the lawyers responded that NBC's characterization to the Colnmission had to be accepted unless it were unreasonable. The Commission found that cliaracterization preposterous. Like Goldilocks tasting Baby Bear's porridge, the FCC pronounced the Accuracy in Media coinplaint just right: NBC had violated the Fairness Doctrine. ${ }^{79}$

NBC's appeal to the District of Columbia Circuit presented several arguinents. It repeated the claim that its own characterization was binding because it was reasonable and also asserted that a liolding agamst NBC would signal the end of muckraking documentaries. Indeed, sucl a holding would be a clear warning to all broadcasters to sliy away from

76. Accuracy in Media, Inc., v. NBC, 44 F.C.C.2d 1027 (1973), rev'd sub nom., NBC v. FCC, 516 F.2d 1101, 1124 n.76 (D.C. Cir. 1974).

77. Id. at 1039.

78. Id. at 1027 .

79. Id. at 1039. 
anything that spelled controversy. As an affidavit from David Brinkley asked, would a program on shoddy highway construction have to devote a reasonable amount of its time to treating the viewers to a visual display of properly constructed roads? ${ }^{80}$

What the "Pensions" case taught was that the Fairness Doctrine and aggressive broadcast journahism would not mix and one was going to go. The three-judge panel appeared to understand this and reversed the Commission, but on the highly questionable ground that the FCC should have given greater deference to NBC's belittling characterization of its program. ${ }^{81}$ As soon as that conclusion was announced, however, the full court voted to hear the case en banc. ${ }^{82}$ Apparently unable to agree on what to do some three years after the program aired, the court then returned the program to the original panel with a suggestion that the recently-enacted federal pension reform laws had mooted the case. ${ }^{83}$ The original panel then sent it back to the FCC with a hike suggestion and the case vamished. ${ }^{84}$ The porridge had gone cold.

What is one to make of a Fairness Doctrine-designed to protect "the right of the public to receive suitable access to social, political, esthetic, moral, and other ideas and experiences"85 - that does not apply to unbalanced reporting about American military strength, air traffic safety, and pension fund security? One might be tempted to conclude that the doctrime has been effectively abrogated by these decisions. Such a conclusion, however, would be wrong. The Commission and the courts occasionally do agree that a case is just right.

d. WXUR. Consider the controversy over the Reverend Carl McIntire's broadcasts. By the mid-1960's when he purchased WXUR, Rev. McIntire, whose program aired on hundreds of radio stations across the nation, was a superstar in the group of highly controversial rightwing radio mimisters. ${ }^{86}$ The transfer of the license was opposed by mainstream civic and rehigious groups in the Philadelphia area who were concerned about having a station in the area that would be controlled by such a man. The Commission granted the transfer application, but took the unusual step of warning McIntire about the obligations of the Fairness Doctrime, which his statement of proposed programming had-nat-

\footnotetext{
80. NBC v. FCC, 516 F.2d 1101, 1124 n.76 (D.C. Cir. 1974).

81. Id. at $1125,1132-33$.

82. Id. at 1155 .

83. Id. at 1156 .

84. Id. at 1180 .

85. Red Lion Broadcasting Co. v. FCC, 395 U.S. 367, 390 (1969).

86. F. FRIENDLY, supra note 71 , at 7 .
} 
urally-promised to satisfy. ${ }^{87}$

When challenged by the same groups again at renewal, McIntire was forced to a hearing. "At the heart" 88 of the proceeding was the Fairness Doctrine. McIntire had been violating it and the personal attack rules in the same way that other stations ran commercials or played Beatles records-he did it as a inatter of course without even thinking about it. Monitoring by both the Broadcast Bureau of the FCC and contplaining groups provided proof that would convict in any capital case. The principal offending show, entitled "Freedonu of Speech," was hosted by Tom Livezey, a inan described by former CBS News President Fred Friendly as possessing a "special talent for attracting those citizens of the City of Brotherly Love who stayed up late worrying about Jews, blacks, radicals, and Billy Graham."89 What follows will allow one to get a gist of the prograni:

CALLER: About this B'nai B'rith Anti-Defamation League . . . why don't they get upset at all this smut and filth that's going through the mails?

LIVEZEY: And who do you think is behind all this obscenity that daily floods our mails, my dear?

CALLER: Well, frankly, Tom, I think it is the Jewish people.

LIVEZEY: You bet your life it is. ${ }^{90}$

Amazmgly, the hearing examiner ruled for WXUR. In a conclusion too neat by half, he in part excused the violations on the ground that WXUR put out so much controversial programming while the station was short on staff that it was mipossible to keep up with all the violations. ${ }^{91}$ His other justification was inore interestimg. No one could deny that WXUR was meeting one of the asserted purposes of the Fairness Doctrine, the presentation of controversial programming. Few stations-and none owned by CBS, NBC, ABC, or the Washington Postcould come close. And as for balance, the hearing examiner held that anyone wishing to hear the other side of the issues presented on WXUR could do so with ease; in the Philadelphia area all other viewpoints were available and no histener need be uninformed. But with the silencing of McIntire that was no longer the case. Prior to his purchase of WXUR, McIntire's type of voice was unavailable in Philadelphia and it becaine so again after the FCC ruled adversely to him. Denying WXUR renewal

87. In re Borst, 4 RAD. REG. 2d (P\&F) 697, 700 (1965).

88. In re Brandywine-Main Line Radio, Inc., 24 F.C.C.2d 18, 21 (1970).

89. F. FRIENDLY, supra note 71 , at 80 .

90. Id. at 81 .

91. See In re Brandywine-Main Line Radio, Inc., 24 F.C.C.2d 42, 53, 70, 71, 135, 138-39 (1968) (initial decision of hearing examiner; lack of attention to personal attacks deemed "less reprehensible" due to shortage of staff), aff d, 473 F.2d 16 (D.C. Cir. 1972), cert. denied, 412 U.S. 922 (1973). 
thus served none of the affirmative purposes of the Fairness Doctrine while in fact reducing both the anount of controversy and the range of available opinion on the air in Philadelphia. ${ }^{92}$

Nice try, but legally irrelevant, held the FCC. ${ }^{93}$ Once Fairness Doctrine violations of that magnitude were found, it held, the excuses provided by the hearing examiner were entitled to no weight. The station was a rogue and death was the only appropriate sanction.

By the luck of the draw, on appeal McIntire drew the most favorable conceivable panel of the District of Columbia Circuit, one including its two most liberal menbers, Chief Judge Bazelon and Judge Skelly Wright. But it was to no avail. The third member, Judge Edward Tamin, agreed with everything the Commission said. ${ }^{94}$ Judge Wright ignored what the Commission said was the "heart" of the matter and instead rehed on McIntire's breach of his promise to obey the Fairness Doctrine rather than on his violations of the Fairness Doctrine, as if somehow that were a distinction of substance. 95 Chief Judge Bazelon authored a rare dissent, against apphication of the doctrine, but it was just that-a dissent. ${ }^{96}$ It was not even enough to pick up the necessary four votes for Supreme Court review by certiorari. Justice Douglas wished to hear the case, but no one else did.97

\section{Incoherence as an Inescapable Feature of the Fairness Doctrine.} The McIntire episode thus demonstrates that the Fairness Doctrine has soine content. The four examples collectively, however, show that the content is incoherent. By what system of logic or intuition could one

92. See id. at 138-39 (initial decision of hearing examiner; removing WXUR from the air would discourage free discussion on the air and deprive listeners of militant viewpoints, thus defeating purpose of the Doctrine); see also Brandywine-Main Line Radio, Inc. v. FCC, 473 F.2d 16, 68-70 \& n.30 (D.C. Cir. 1972) (Bazelon, C.J., dissenting) (FCC's strict rendering of faimess requirements deprives radio audience of "robust debate on imnumerable controversies" and will have chilling effect on other broadcasters) (citing In re Brandywine-Main Line Radio, Inc., 24 F.C.C.2d 42, 134 (1968), cert. denied, 412 U.S. 922 (1973). McIntire's own radio program had been cancelled by its only Philadelphia outlet prior to his purchase of WXUR, and he believed his viewpoint was not available in the market. 24 F.C.C.2d at 44-45. There was no indieation in the record that in the tine McIntire operated WXUR another equivalent substitute entered the market.

93. 24 F.C.C.2d 18, 27, 33 (1970) (decision of FCC) (failure to comply with requirements of Fairness Doctrine not excusable because of size of staff or unavailability of alternative outlet for airing controversial views).

94. Brandywine-Main Line Radio, Inc. v. FCC, 473 F.2d at $60-61$ (finding "no justification for upsetting a sanction so well substantiated by the record and findings of the Counmission").

95. See id. at 62-63 (Wright, J., concurring) (concurrence based on licensee's deceptivc promise to Commission to comply and subsequent treatment of public license as if "it were private property nonencumbered by public obligations").

96. Id. at 63-80 (Bazelon, C.J., dissenting).

97. Brandywime-Main Line Radio, Inc. v. FCC, 412 U.S. 922 (1973) (Douglas, J., would grant cert.). 
predict that a bevy of commissioners and judges setting out to protect the public's right to hear all sides of controversial issues would find that, of these four broadcasters, WXUR and only WXUR presented a target worthy of their firepower?

We believe the cases deinonstrate an inherent dilemma in the Fairness Doctrine. If the doctrine is to be taken seriously then suspected violations lurk everywhere and the FCC should undertake continuous oversight of the industry. If the FCC will not-or cannot-do that, then the doctrine inust be toothless except for the randomly-selected few who are surprised to feel its bite after the fact. Furthermore, as the McIntire facts demonstrate, it is likely that the egregious cases where enforcement will occur will continue to involve stations that air significantly inore controversial programming than the average. Thus, the doctrine will be enforced against those who best serve one of the stated purposes of the Fairness Doctrine: broadcasting controversial programming. The Fairness Doctrine is at war with controversy and diversity.

Opponents of the Fairness Doctrine can describe easily how the cases described above sliould have been handled. The results in the network cases were correct-although not for the reasons given-because of the "profound national commitinent to the principle that debate on public issues should be uninhibited, robust, and wide-open."98 And, so long as radios have dials, the McIntire case was wrongly decided.

Proponents of the Fairness Doctrine have to explain either how the outcoines in these cases can be reconciled satisfactorily or how a differently admmistered doctrine could yield coherent results in these cases. The inost obvious ground for reconciling the actual results is that television network programming is exempt from the doctrine. This rationale, however, fails to explain other cases and, inore inportantly, leaves one wondering why anyone else should be subject to it.

If proponents inean to defend a doctrine that might exist, but never has, our best guess is that they beheve all three network cases are wrongly decided. Certainly any lesser claim would still leave a toothless and incoherent doctrine. Yet, if the network cases were wrongly decided, the doctrine's proponents still inust answer several questions. What if the network contends, as in Private Pilots, that the program was true and the asserted opposing viewpoint is false? Would it have been sufficient, as the FCC argued in $N B C$, for NBC to provide time on the "Today Show," an early morning program, for views opposing the dommant theme of Pensions, a prime time "documentary?"99 If tlie passage of pen-

98. New York Times Co. v. Sullivan, 376 U.S. 254, 270 (1964).

99. See F. FRIENDLY, supra note 71, at 156. 
sion reform legislation mooted the $N B C$ case, did the coverage of the Russian invasion of Afghamistan, the candidacy of Ronald Reagan, or the deployment of Pershing missiles in Europe moot the ASCEF complaint, which centered on events in 1972-73?

These are serious questions that strike at the heart of the issue whether the Fairness Doctrime has, or could have, any intelligible content. For opponents of the doctrime, however, it would be specious to try to answer them. But it is not unfair to ask. If the Fairness Doctrine is to survive the assaults presently levelled at it, surely those who would choose to retain the rule owe an obligation to explain what it is.

\section{CONCLUSIONS}

We do not beheve Goldilocks would have stayed in the Three Bears' house for over forty years had she always found the porridge, chairs, and beds too hot or too cold, too big or too small, too hard or too soft. Similarly, the FCC should abandon, or be forced to abandon, a doctrinenow in its fifth decade - that violates every accepted primciple of first amendment jurisprudence, represents an ill-advised and inefficacious regulatory policy, and has no ascertainable content.

Honorimg the journalistic ethic of thorough and balanced coverage is a noble goal. Legislating and enforcing such behavior, however, is at best a meaningless and futile gesture, at worst a counterproductive and unconstitutional act. If every generation nevertheless must indulge itself in one such gesture, it would be far better to bring back the 1962 Mets than to retain the Fairness Doctrime. 